B 203

\title{
数值解析によるロケット打上げ時の音響振動に関する研究
}

村上 桂一○( (独) 宇宙航空研究開発機構), 高橋 孝 ( (独) 宇宙航空研究開発機構), 北村 圭一(名古屋大学), 橋本 敦 (独) 宇宙航空研究開発機構), 青山 剛史 (独) 宇宙航空研究開発機構), 中村 佳朗 (名古屋大学)

\section{Computational Research on Vibro-Acoustics at Rocket Launch}

\author{
Keiichi MURAKAMI, Takashi TAKAHASHI, Keiichi KITAMURA, \\ Atsushi HASHIMOTO, Takashi AOYAMA and Yoshiaki NAKAMURA
}

\begin{abstract}
A study to establish a numerical prediction method for vibro-acoustics during rocket launch has been conducted. This method consists of some analysis elements: numerical analysis of sound generation, propagation, transmission, and vibro-acoustics of payload. In this paper, sound pressure distributions obtained by these analyses are visualized. At first, flow and acoustic fields of modeled H-IIA launch pad are shown, which is obtained by a hybrid methodology of the Euler and Linearized Euler Equations (LEE) solvers. Then, an arch-shaped transmission wave is observed from a sound transmission analysis of hollow wall model using the Finite Difference Time Domain (FDTD) method. Finally, it is clearly shown that the acoustic field is affected by structural vibrations and the coupled vibro-acoustic problem of flexible satellite model can be solved by the Wave Based Method (WBM).

Keywords: Numerical Analysis, Acoustic Transmission, Vibro-acoustics, Rocket Launch
\end{abstract}

\section{1.はじめに}

H-IIA ロケット 204 形態及びH-IIBロケットなどでは, SRB（固体ロクットブースター）の増加やメインエンジ ンのクラスター化に伴うロケット打上げ時の音響環境悪 化が懸念されている，そこで，口本の射場やロケット形 態にも適用可能な，搭載衛星の音響振動に関する予測方 法を確立することが重要であり，数值的なアプローチに よるロケットフェアリング及び衛星の流体・音響・振動 連成解析の吥究が JAXA で進められている.この解析に 必要な要素技術として，「音源解析」：プルームに起因す る音源解析，「伝播解析」：反射や回折を含む音響伝播解 析，「透過解析」:フェアリングを透過する音波の解析，

「音響振動解析」: フェアリング内に伝わった音波が搭載 衛星などに及ぼす影響の解析などが挙げられる。

高次精度の数値解析を用いると, 得られた計算結果か ら大気圧との差圧の分布を可視化し, 音波の影響を客観 的に目で見ることができる，本稿では，前段で述べた口 ケット打上げ時の音響環境予測のための要素解析の計算 結果を可視化し，圧力波が伝わる様子や，構造物が音波 によって振動する様子について述べる。

\section{2. ロケット打上げ時に発生する圧力波の解析}

\section{1 排煙溝から放出される圧力波の伝播解析}

ロケット打上げ時には, 複数の音源から出た音が, 射 場周囲の地形やPST (射点整備塔) などの射場建造物に よる反射や回折を経て，ロケット軌道上に到達し，干涉 する.これらの影響を考虑した音響伝播解析のために， ロケットプルーム流えの影響を考慮可能な Euler/LEE(線 形オイラー方程式)ハイブリッド計算コード1)を用いた.

解析例として，モデル化した H-IIA ロケット射場のフ レームデフレクタ（偏向板）とダクトから成る排煙溝

(Fig. 1) に，LE-7A の排気プルームを模擬したジェッ トを流入条件として与えた場合の解析を行った2).Fig. 1 に対称面内の音圧分布を示寸. 図の右側が Euler 解析領 域, 左側が LEE 解析領域である. この図から, 排煙溝 出口から放射された压力波がロケット打上げ軌道に到達 していることが分かる。

\section{2 フェアリングモデルの音響透過解析}

音響透過解析の第 1 段階として，流体・固体中を伝播 寸る弾性波を同時に解析できる 2 次元マルチブロック計 算コードを作製した。解析手法には，Finite Difference Time Domain (FDTD)法3）を用いた。

解析例として，流体巾に置かれたハニカムサンドイッ チ構造をモデル化した巾空壁を透過する入射正弦波の計 算を行った ${ }^{4 l}$. Fig. 2 に, 巾空壁内外の応力分布を示卞. 
流体よりも固体のほうが弾性波の伝播速度が速いので, 中空部を透過入射波が伝播する間に, コア部を弾性波が 綝返し往復する. 図の上部流体部に見られる透過波は, コア部を中心として弧を描いて広がり，周期境界条件に よって左右の境界から入射する波とお互いに干涉する様 子が捕らえられた。

\section{3 衛星モデルの音響振動解析}

ロケットのフェアリング内に搭載された衛星などの音 響振動を予測するため, 内部定常音響構造連成問題の解 析手法として, 波動ベース法(WBM : Wave Based Method $)^{5)}$ に着目した. WBM の注目すべき性質は, 支 配方程式を厳密に満たす波動関数で解を展開するため, 空間離散化をする必要がないことである. 従って, FEM 等による音響振動解析で問題となる数值分散誤差が無い ので, 広い周波数帯を含む音響振動の予測が可能である.

解析例として, ロケットに搭載された柔軟衛星 2 次元 モデルに対し，フェアリング内壁に地上音響試験で用い られる音圧レベルを課した定常音響振動解析の結果を示 す ${ }^{6)}$. 柔軟衛星モデルは, 5 つの両端固定の平板から構 成される. Fig. 3 は, 励振周波数が $500 \mathrm{~Hz}$ のときのフェ アリング内音場を表している.この図から，衛星モデル の側面と上面とでは音圧分布が異なることが分かる.

\section{3. まとめ}

ロケット打上げ時の音響振動予測に関する要素技術で ある音響伝播・透過・振動解析について, それぞれの特 徵的な解析結果を可視化し, 音波の様子を視覚的に示し た. 今後は, 各々の解析精度を向上させつつ, 打上げ時 の䡣音がフェアリングに到達し, 内部に透過して衛星を 振動させるまでの一連の現象をシミュレーションできる 統合音響解析システムの構築へ向けた研究を進める.

\section{参 考文 献}

1) Men'shov, I. and Nakamura, Y.: Implementation of the Variational Riemann Problem Solution for Calculating Propagation of Sound Waves in Nonuniform Flow Fields, Journal of Computational Physics, Vol. 182 (2002) pp.118-148.

2) Kitamura, K., Hashimoto, A., Murakami, K., Aoyama, T. and Nakamura, Y.: High Resolution CFD/CAA Hybrid Analysis of Supersonic Jet Interacting with Walls, AIAA Paper AIAA-2007-3871 (2007).

3）佐藤正弘：FDTD 法による弾性振動・波動の解析入門, 森北 出版 (2003)

4）村上桂一, 青山剛史 : FDTD 法によるハニカムモデルの音響 透過解析, 第 39 回流体力学講演会/航空宇宙数值シミュレ ーション技術シンポジウム講演集 (2007) pp. 209-212.

5) Desmet, W.: $A$ wave based prediction technique for coupled vibro-acoustic analysis, $\mathrm{Ph}$.D. dissertation, K.U. Leuven (1998).

6) 高橋孝, 村上桂一, 青山剛史, 相曾秀昭 : 搭載宇宙機の音 響構造連成解析手法に関する研究, 第 39 回流体力学講演
会/航空宇宙数値シミュレーション技術シンポジウム講演 集 (2007) pp. 213-216.

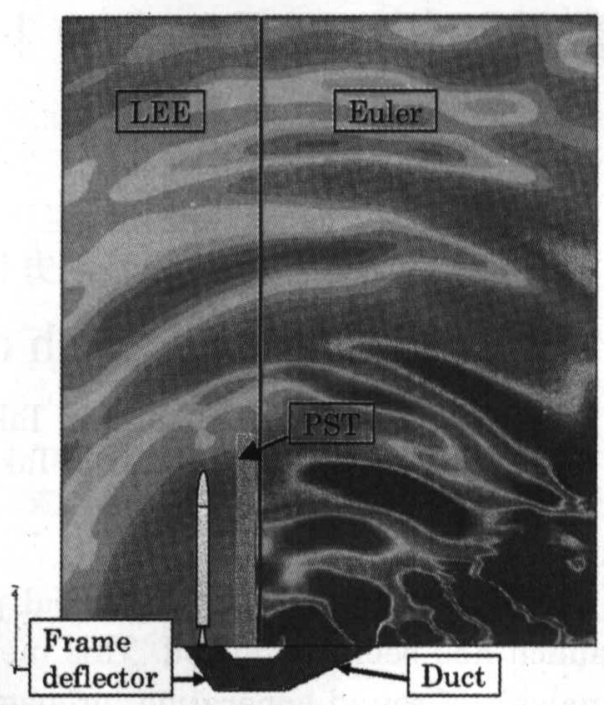

Fig. 1 Pressure wave propagation around the H-IIA launch pad model

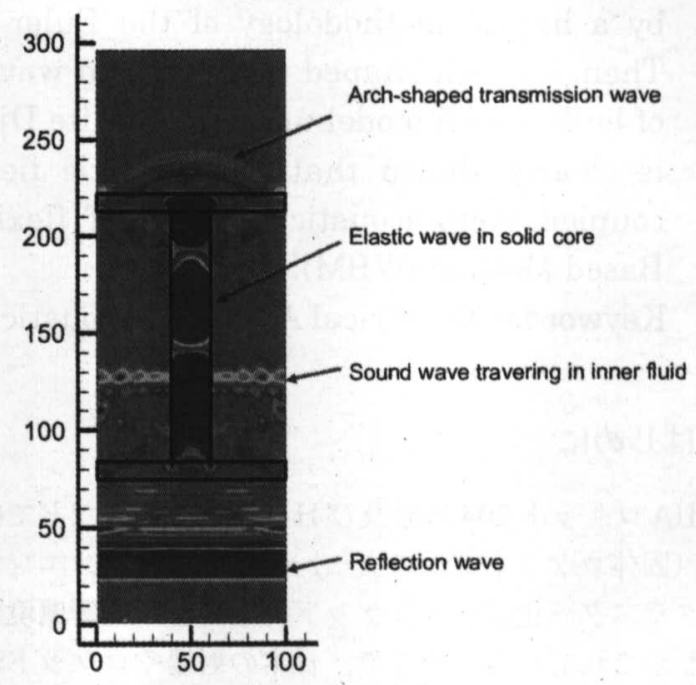

Fig. 2 Pressure and normal stress contours of a hollow wall model

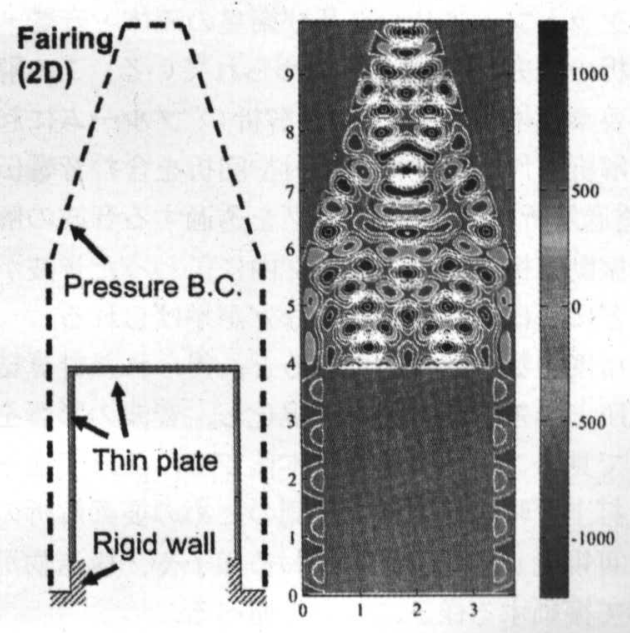

Fig. 3 Sound pressure inside of fairing for a flexible spacecraft model $(500 \mathrm{~Hz})$ 